THE decision made last year that Britain's next commercial reactors should be of the steam generating heavy water type (SGHWRs) has given a predictable fillip to morale at the United Kingdom Atomic Energy Authority's research establishment at Winfrith, Dorset, where the 100-MW prototype has been supplying electricity to the grid for more than seven years. And not suprisingly, a greater proportion of Winfrith's annual spending of £9 million (of which $£ 5$ million represents payment for the electricity Winfrith supplies to the national grid) is being channelled into work on the SGHWR, at the expense of some of the establishment's other activities.

The Winfrith SGHWR has the rare distinction of being based on a design for a reactor more than five times its size, which means that scaling up to a commercial reactor of perhaps $660 \mathrm{MW}$ (a size which matches the capacity of the electricity generating equipment now widely used in Britain) should be child's play by comparison with the same exercise for the British advanced gas cooled reactors (AGRs); the AGR programme in Britain is hopelessly behind time and still far from complete.

The secret is that an SGHWR is really a collection of mini-reactors of about 1 MW strung together. As the diagram shows, the basic building block, a pressure tube assembly, is remarkably simple: water at high pressure enters at the bottom and emerges from the top as steam which is fed to the turbines. Put 104 of them together in parallel and you have the Winfrith reactor, or a reactor of almost any desired size by varying the number.

Although Winfrith will continue to be interested in the kind of research that is best carried out on a prototype reactor-testing of new component designs and materials, for exampleit will be for the Nuclear Power Company to finalise the design details for the first commercial SGHWR.

Presumably at that time, too, people will start to talk again about the prospects for exporting SGHWRs. Although the potential customers of a few years ago, such as Australia, Greece and Finland, are probably lost, it is at least now possible to say as part of a sales pitch that electricity utilities in Britain are also buying them.

- MORE than a year since energy policy became a hot parliamentary property, the British Secretary of State for Energy, Eric Varley, continues the tradition of the committees under his purview by appearing before Commons sub-committees, armed with good intentions. When he first appeared before the Energy Resources Sub-committee of the Select Committee on Science and
Technology, Mr Varley said last year that since he had only been at the job for three months it was early days for him to be formulating hard and fast policy. But he promised he would do his swotting up while listening to all kinds of advice. A little later his Advisory Council on Energy Conservation came before the same sub-committee and said that they too were open to suggestions, though they had precious

\section{Energy in Britain}

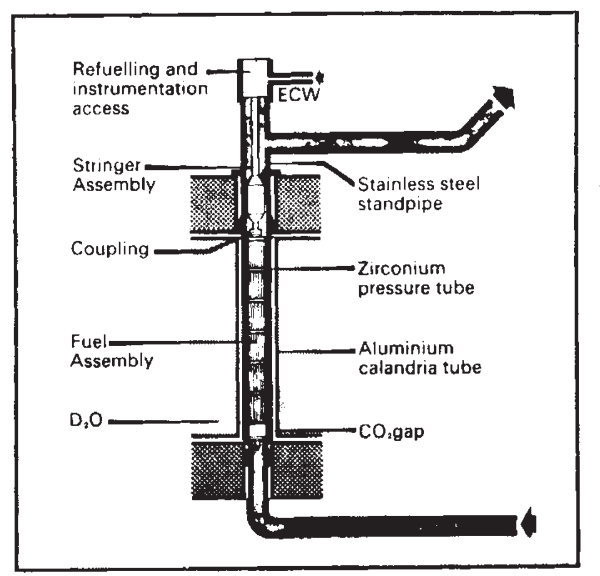

SGHWR boiling channel

few of their own to offer. Then followed, earlier this year, Varley's new Chief Scientist, Harwell wunderkind Walter Marshall, who virtually burst at the seams with enthusiasm while regretting that it was yet, alas, too soon to be expecting any energy blueprint.

Now Mr Varley has made a return appearance before the Commons energy group, who left him with what one Member of Parliament described as a flea in his ear. Which is to say they gave him to understand that they were not entirely bowled over by the progress of the Labour government's energy strategy. Reviewing the state of the game, Mr Varley harped on his December campaign of exhortation once too often for Labour member $\mathrm{Mr}$ Ronald Brown. The 'Save It' campaign was 40-year-old thinking, $\mathrm{Mr}$ Brown suggested. And the Energy Secretary's plea that people should economise by keeping their refrigerators threequarters full was "pedestrian".

$\mathrm{Mr}$ Brown went so far as to suggest that the energy chief was in thrall to bodies of important chaps who were so busy beavering away at their uncoordinated committees that the whole energy package was turning out to be a "hotch potch". The chosen big-wigs were generally firm about the things which could not be done, but less firm about suggesting what could be done, said Brown, naming Ieuan Maddock (Chief Scientist at the Department of Industry) as the "godfather" of the gang. Mr Brown asked whether or not $\mathrm{Mr}$ Varley had the right people on the job (the energy conservation group are in fact part-timers) and the committee chairman, Arthur Palmer, confessed he had the distinct impression that Chief Scientist Marshall had too much on his plate, what with running Harwell and sitting on all those committees.

Not so, replied the Secretary of State, stoutly. Marshall wasn't complaining about overwork, and the advisory boards were manned by chaps with enormous experience. If they didn't appear to be pulling up trees it was worth bearing in mind that only $1 \%$ of energy used in the country was under government control, the rest being used by private industries which the government could simply advise. Alas, Mr Varley was leading with his chin. Apparently, one of the Department's advisory groups, the Advisory Council for Research and Development of Fuel and Power (ACORD) has been busying itself with the energy problems of the nationalised industries only, when its brief placed no such restriction on its activities.

When this was pointed out to Mr Varley, along with a suggestion that it was unrealistic to plan national energy policy by investigating only the nationalised concerns, the Secretary of State lcoked moderately sick and conceded that it was "a very good point" which had not been brought home to him before, and which he would look into.

As for the statistics, which caused him to brighten, at the outset, $\mathrm{Mr}$ varley reported oil imports running recently at a yearly rate of less than 100 million tons, with the likelihood of even lower levels to come. This figure compared with 112 million tons in 1973 and 109 millions tons in 1974. Total energy consumption in 1974 was $4.5 \%$ down on the previous year and inland deliveries of oil in January this year were $4 \%$ down on the figure for 1974 and nearly $13 \%$ less than for January 1973. Petrol consumption, which normally rises at an annual rate of $7 \%$ was $5 \%$ down last January on the figure for January two years earlier.

But the committee wanted to know how much of this cut-back was positively caused by implementation of the Department of Energy's fuel-saving policy, and how much was caused by the general industrial recession. Not possible to say, claimed Mr Varley, but he promised to have somebody make the attempt. Certainly it can't all have been caused by a sudden overstocking of refrigerators. 